\title{
Measuring the Degree of the Presence of Learning Organization Dimensions at the Branches of Commercial Banks in the Governorate of Almafraq - Jordan
}

\author{
Dr. Bahjat Eid Al-jawazneh (Corresponding author) \\ Assistant Professor \\ Department of Business Administration, Faculty of Business \& Finance \\ Al-albayt University, Mafraq, Jordan \\ E-mail: jawazneh9@yahoo.com \\ Dr. Waleed M. Al-Awawdeh \\ Assistant Professor \\ Department of Business Administration, Faculty of Business \& Finance \\ Al-albayt University, Mafraq, Jordan \\ E-mail:walawawdeh@yahoo.com
}

Received: June 13, 2011

Accepted: July 6, 2011

Published: November 1, 2011

doi:10.5539/ijbm.v6n11p27

URL: http://dx.doi.org/10.5539/ijbm.v6n11p27

\begin{abstract}
The prime aim of this study, is to find out if the Commercial Banks in Almafarq Governorate in Jordan have the suitable and healthy learning environment through the presence of the learning organization dimensions, which were identified by (Watkins and Marsick 1996, 2003), The Commercial Banks operating in the governorate of Mafraq were chosen to be the focus of this study. The population of the study consisted of all employees of these commercial banks, and because of their limited number, the researchers, took all of them as the entire population of the study to make results more credible and tenable.

The major finding of this study states that, Commercial Banks in the city of Mafraq are learning organizations, but the presence of learning environment is just slightly above average, and therefore, the management of these branches needs extra efforts in the future to nurture the learning culture.

Keywords: Learning organization, Learning dimensions, Commercial Banks, Jordan

\section{Introduction}

The Ottoman Bank inaugurated in 1925, marked the beginning of banking operation of the Jordanian banking sector. The Ottoman bank which was founded in Turkey in 1863 is the oldest banking institution in the region, and worked as the financial agent of the Government of Jordan, and still works in Jordan even to this day under the name "Bank of Grindlays" (al-horani, 1979).

Now adays the world witnesses unperceivable global competition, due to the information and communications technology advances, and changing market demands. The commercial banks in Jordan constitute learning organizations. In a learning organization, employees continually create, acquire, and transfer knowledge helping to help their companies to be adapted to the unpredictable faster than rivals can.

The learning organization concept has been known to business organizations for many decades (Watkins and Golembiewski 1995; DiBella 1997; Roth and Kleiner 1998; Van der Bent et al. 1999). It is defined as an organization that is skilled at creating, acquiring, and transferring knowledge, and at modifying its behavior to reflect new knowledge and insights (Garvin, D., 1993).

Learning organizations are designed to increase competitiveness through generative learning that is looking forward and reducing the major shocks of change, through close relationships with customers and other key constituents that allow for mutual adjustment, and through the ability to quickly reconfigure and reallocate resources based on environmental change (Slater \& Narver,1995).

There is a saying: "If you can't measure it, you can't manage it" which means that managers are not only responsible for fostering the culture of learning in their organizations but also making sure through scientific methods that the learning culture exists and to attain as an expected outcome. Hence Jordanian commercial banks are required to know where they are standing at the moment in terms of their ability to compete and adapt through the presence of the suitable learning environment.

Many researches show that organizations that apply the Learning organization concept can come over the
\end{abstract}


obstacles of change (Nonaka 1991; Garvin 1993; Prokesch, 1997). Therefore, it has been proposed that becoming a learning organization is an opportunity for organizations not only to gain a competitive advantage in an unstable business environment, but also to keep ahead of the dramatic rapidity of change (Stata 1989; Senge 1990a; Hedgetts et al. 1994; Hitt 1995).

\section{Related literature and studies}

\subsection{Learning Organization}

The concept of learning organization originated by (Senge 1990). In his book The Fifth Discipline, Senge described the learning organization as a place where people continually expand their capacity to create the results they truly desire, where new and expansive patterns of thinking are nurtured, where collective aspiration is set free, and where people are continually learning how to learn together.

Watkins and Marsick (1993) argued that the learning organization was not a collection of individuals learning within the organization; rather they considered it as a process occurring at different levels of the organization. Organizational learning is not a goal in itself, related to individuals' behavior in an organization, and, as a result, to the organization's ability to respond more effectively to its environment (Murray and Donegan, 2003). DiBella and Nevis, 1995 shared the viewpoint that, learning happens in any organization and therefore any type of organization can be a learning organization - businesses, educational institutions, nonprofits, community groups.

Argyris and Schon's, (1978) model of organizational learning, introduces the concepts of single and double loop learning. The first is concerned with responding to changes in the environment without changing the core set of organizational norms. The second, on the other hand, occurs when organizations respond to changes in their environment by challenging and redefining underlying assumptions and organizational norms. Double loop learning is tightly coupled with the organization's ability to adapt its learning processes, or to control how it learns.

Many scholars depicted the learning organization through three levels, the individual level, the group level, and the organizational level (Cummings \& Worley, 2001, Watkins and Marsick, 1996). The five-discipline model suggested by (Senge, 1990) implicitly brings in these three levels of learning: the individual level (mental models and personal mastery), the group level (team working) and the organizational level (shared vision and systems thinking)

\subsection{Dimensions of Learning Organization}

Watkins and Marsick (1996, 2003), developed the dimensions of the Learning Organization Questionnaire (DLOQ), to assess the extent to which an organization meets certain criteria as a learning organization. It had been validated by (Yang et al., 2004) as a research tool, and they asserted that Learning can be embedded in the organization and resulted through the implementation of seven dimensions on the individual, team and organizational level, These dimensions are:

2.2.1 Individual level

1. Creating continuous learning opportunity

The efforts exerted in designing and implementing both formal and informal learning, including the redefinition and reimplementation of effective learning for individuals and learning facilities development. Learning organization facilitates the learning of all its members and continuously transforms itself (Pedler et al., 1991).

2.2.2 Promoting inquiry and dialogues

Related to efforts in creating the appropriate environment that makes individuals become a lot more open minded, today's learning organizations create environments where experiential knowledge is learned through dialogue and interaction day-by-day.

\subsubsection{Team Level}

\section{Encouraging collaboration and team learning}

This can be achieved through the creation of shared perspective and vision, thus, it requires a strong organizational culture to overcome the differences that may happen and create misunderstandings and conflict. Team learning, reflects the "spirit of collaboration and the collaborative skills that under gird the effective use of teams"

A learning organization is organized in such a way that scans information in its environment, creates information by itself, and encourages individuals to transfer know-ledge among the individuals in team (P.E. Jensen 2005).

2.2.4 Organizational Level

1). Establishing system to capture and share learning

An Organization's capacity development is aimed for new thoughts that have to be shared throughout the organization. The result of learning has to be collected within the system, so anything that has been learned may also be used by people within the organization on any level at any time.

2). Empowering people towards a collective vision

Signifies an organization's process to create and share a collective vision and get feedback from its members about the gaps between the current status and the new vision. 
This is aimed to strengthen people's participations into autonomy. Through autonomy, individuals are considered to be having a lot more directive power, thus, providing them with opportunities to make qualified initiatives. Therefore, a learning organization cannot succeeded without a shared vision (Senge, P.M., 1990).

3). Connecting the organization to its environment

There are strong relationships between the internal and the external environment of a learning organization. Attached to internal environment is to be responsive to the needs of their members, while the connection with the external environment means that every demand of the external customers will affect the entire organization, including the community where the organization operates, competitors and stakeholders.

4). Providing a strategic leadership for organizational learning

To become a learning organization, requires a leadership that could direct, facilitate and create dynamism. Cultural values in an organization need to be supported by managers or leaders. Leaders have important roles in a learning organizations since they not only originate commitment to change but also enhance the employees' ability to learn (Senge, 1996).

\subsection{Related studies}

Garvin (1993) suggested that learning at operational, policy and strategic levels needs to be conscious, continuous and integrated; and that management is responsible for creating an emotional climate in which all staff can learn continuously.

Örtenblad (2002) suggested that there are four understandings of the learning organization concept. The first is the old organizational learning perspective, which focuses on the storage of knowledge in the organizational mind. Learning is viewed as applications of knowledge at different levels. The second type is the learning at work perspective, which perceives a learning organization as an organization where individuals learn at the workplace. The third is the learning climate perspective, which exemplifies the learning organization as one that facilitates the learning of its employees. The fourth is the learning structure perspective, which regards the learning organization as a flexible entity.

Bates R. \& Khasawneh S. (2005) examined the relationship between organizational learning culture, learning transfer climate, and organizational innovation in Jordanian organizations. The results showed that organizational learning culture predicted learning transfer climate, and both these factors accounted for significant variance in organizational innovation.

In their study on Assessment of development of the learning organization concept in Jordanian industrial companies (Abu Khadra M., \& Rawabdeh I., 2006) examined the impact on organizational performance of the application of management and human resource practices, and attempted to outline key elements and assess development of the learning organization (LO) concept in Jordan. The results of the study indicated that the learning organization concept can be explored in Jordanian industry using eight constructs. These constructs were found to be strongly correlated. In general, the study also identified basic steps in the process of transformation into a learning organization in Jordan.

Kontoghiorghes, C., et al (2005) aimed at examining the relationship between certain learning organization characteristics and change adaptation, innovation, and bottom-line organizational performance. The learning organization characteristics such as; open communications and information sharing, risk taking and new idea promotion, and information, facts, time, and resource availability to perform one's job in a professional manner, were found to be the strongest predictors of rapid change adaptation, quick product or service introduction, and bottom line organizational performance.

\section{Statement of the problem}

Senge (1990) stated that Learning organizations would be able to adapt to the unpredictable environments more quickly than their competitors could, and would be also able to reap the fruit of their success faster than rivals.

Banks in Jordan are also Organizations that confront a lot of challenges on both local and t global aspect, such as the stiff competition and the global and regional unrest, hence searching for best ways to face challenges is a demanding task that commercial banks in Jordan must carry out, and one of the approaches is, to be a learning organization.

There are contradictory revelations concerning the degree of the learning environment presence at the commercial banks branches at Almafraq Governorate according to the results of the unstructured interview the researchers conducted with some employees in these banks. Therefore, the researchers found a need to conduct this research.

Inspired by the above conclusion, the researchers tried to find out if the commercial banks in Almafarq Governorate in Jordan have the suitable and healthy learning organization environment through the presence of the learning organization dimensions which were identified by (Watkins and Marsick, 1996, 2003)

\section{Research objectives}

This research aims at answering $\mathrm{f}$ the following question:

At what degree the learning organization environment is present in the Commercial Banks branches at Almafraq governorate in terms of the following:

- $\quad$ Creating continuous learning opportunities. 
- $\quad$ Promoting inquiry and dialogue strategies.

- $\quad$ Encouraging collaboration and team learning.

- $\quad$ Establishing systems to capture and share learning

- $\quad$ Empowering people towards achieving collective vision.

- $\quad$ Fostering connecting the organization to its environment

- $\quad$ Leadership model that supports learning.

\section{Research hypotheses}

This study tests the following main null hypotheses:

H0. The learning organizations environment is not present at a high degree in the Commercial Banks branches at Almafraq Governorate in Jordan. From the main hypothesis the researchers derived the following sub-hypotheses:

H0a. Commercial Banks branches do not create continuous learning opportunity.

H0b. Promoting inquiry and dialogue is not present in the commercial banks branches.

H0c. Commercial Banks branches do not encourage collaboration and team building.

H0d. Systems are not established in the Commercial Banks branches to capture and share learning.

H0e. People are not empowered toward a collective vision at the Commercial Banks branches.

HOf. Commercial Banks branches are not connected to their environment.

H0g. Commercial Banks branches do not possess leadership model that supports learning.

\section{Research methodology}

The Commercial Banks operating in the Governorate of Mafraq were chosen to be studied for reasons related to the specificity of this region, since it was declared by His Majesty King Abdullah II, as a free economic zone, after the Aqaba special economic zone, and therefore it is getting a lot of care and attention from the government at all levels, aside from that the Almafraq Governorate is the second in terms of area (30\% of the total area of the Kingdom), with a population of (250000) people. This research adopted a descriptive research method, and applied the survey of (Watkins and Marsick 1996, 2003) who developed the Dimensions of the Learning Organization Questionnaire (DLOQ), to assess to what degree organizations meet the criteria of the a learning organization environment. This structure provides a model for the researchers to study learning organization dimensions. Research results revealed evidence of internal consistency and the construct reliability of the dimensions of the learning organization (Yang, et.al, 2004).

The researchers also consulted some academicians and practitioners from the banking sector who agreed that, the research instrument is capable of measuring the learning organization environment since it is tested and had been used by many researchers. The instrument is composed of the two parts:

The first part covered the demographic profile of the respondents, while the second covered the learning organizations dimensions.

Nominal scale was used to get the answers of the respondents on their demographic profile. Likert's scale was used to allow respondents to rate the degree of presence of the learning organization environment, which is ranging from strongly agree as the highest and strongly disagree as the lowest.

\subsection{Population and Sample of the study}

The population of the study consisted of all the employees of commercial banks at Almafraq governorate-Jordan, and their number is within the reach of the researchers, researchers decided to take the entire population of the study to make results more credible, thus 110 questionnaires have been distributed to all employees working in these banks, and 99 or $(90 \%)$ of the questionnaires were retrieved, 34 were excluded for not meeting validation requirements, hence 65 or (about $65.5 \%$ ) of the questionnaires were valid for analysis.

\subsection{Data Collection Procedures}

The researchers made use of the secondary source of data such as references and published researches in the field of learning organization and organizational development, which contributed to the development of the theoretical framework and allowed researchers to gain more understanding on the topic. In addition to that Primary data were also obtained through the main instrument which is a survey questionnaire.

\subsection{Test Reliability and analysis of the coefficient of internal consistency}

The test items reliability appeared in the questionnaire was conducted, factor analysis was analyzed by using the statistic package for the Social Science (SPSS) and all indicated a satisfactory level.

Table 1 shows the values of coefficient of internal consistency of all variables of the Learning organization dimensions, with a result of $84.5 \%$ which is acceptable since it is more than the minimum required percentage which is $60 \%$ for social science researches (Cronbach, 1951).

Insert Table 1 here

6.4 Data Statistical treatment

Several statistical techniques have been applied in this study such as; 
1. Descriptive analysis such as: Averages and standard deviations.

2. One sample t- test was used to test the main hypothesis.

For the sake of discussion and interpretation of results of the study, the researchers applied on the following equation to compute the range:

Range $=$ (the highest average value- the lowest average value) / (number of levels): $(5-1) /(3)=1.33$

Therefore the results will be as the following:

1- Results between (1-2.33) represent a week average response rate.

2- Results between (2.34-3.67) represent a medium average response rate.

3- Results more than (3.68) would be a high average response

\section{Findings presentation and results discussion}

7.1 Answering the main question of the research which is, at what degree the learning organization environment is present in the Commercial Banks branches at Almafraq Governorate, taking into consideration the learning organization dimensions identified by (Watkins and Marsick 1996,2003).

\section{Insert Table 2 - here}

The Learning organization environment is highly present at the Commercial Banks in Almafraq Governorate, with a mean of 3.87. Encouraging collaboration and team learning was the most dominant dimension with a rating of 3.95 and a standard deviation of 0.0 .935 , followed by establishing system to capture and share knowledge with a mean of 3.94 and a standard deviation of 0.864 . Promoting inquiry and dialogues showed the least among respondents rating with a mean of 3.75 and a standard deviation of 1.003 .

What is being shown in table 2 manifests that, management of Commercial Banks in Jordan in general, and in Almafraq Governorate in particular is aware of the effect of learning organization environment on the performance of these banks, aside from that the Jordanian government is adopting an open market economy which will leave no place for any backward management style in the financial market place.

Testing the first main Null Hypothesis H0; The learning organizations environment dimensions are not present in the commercial banks branches at Almafraq Governorate in Jordan.

\section{Insert Table 3 - here}

Table(3) shows that the first main hypothesis is rejected because the $t-$ value is more than the tabulated (t) $(33.825>1.96)$ and under the significance level of $(\alpha \leq .05)$, therefore the alternative hypothesis(H1) was accepted, This confirms that the branches of Commercial Banks in the Almafraq Governorate are learning organizations, and at the same time share the same conclusion of (DiBella and Nevis, 1995) who believed that learning happens in any organization and therefore any type of organization can be a learning organization, therefore, that could also be applied to banking sector.

7.2 Testing the first sub-hypothesis H0a, that states; Commercial Banks branches in Almafraq Governorate do not create continuous learning opportunity

\section{Insert Table 4 - Here}

In terms of continuous learning shown in table 4, continuous learning dimension was rated high since it scored an average of 3.90 with a standard deviation of 0.828 , but the item that is related to the freedom of discussing mistakes openly in order to learn from them got the highest in rating with a mean of 4.25 , followed by they identified skills they need for future work tasks, with an average of 3.89 but the lowest in rating is the item" in my organization people are rewarded for learning. This is a cause for optimism because learning on an ongoing basis is a healthy sign for any organization that wants to become capable of learning, and survival especially with regard to the banking sector

\section{Insert Table 5 - here}

Table (5) shows that the first sub hypothesis is rejected because the t- value is more than the tabulated (t) (9.811> $1.96)$ and under the significance level of $(\alpha \leq .05)$. Therefore the alternative hypothesis(H1a) is accepted, This clarifies how much attention the continuous learning dimension is receiving from the Commercial Banks management in the region of Mafraq, because the sector is vital and at the same time needs to be responsive to any change in the external environment.

7.3 Testing the second sub-hypothesis H0b, that states; Commercial Banks branches in Almafraq Governorate do not promote inquiry and dialogue

\section{Insert Table 6 - Here}

Table 6 reveals the above average response rate (3.75) on the promotion of dialogue and inquiry which is considered to be an essential ingredient to any organization that aims to promote the culture of learning, but treating each other with respect got the highest rating (3.71) because the value of respect is embedded in Arabic culture, followed by people spend time building trust with each other (3.79), the least in rating is asking what others think when someone states his view.

\section{Insert Table 7 - here}

Table(7) confirms that the first sub hypothesis is rejected because the $t$ - value is more than the tabulated (t) 
(11.475> 1.96) and under the significance level of $(\alpha \leq .05)$, therefore the alternative hypothesis(H1b) is accepted, which means that management in these banks put emphasis on the aspect of the promotion of dialogue and inquiry in their organization..

7.4 Testing the third sub-hypothesis H0c, that states; Commercial Banks branches in Almafraq Governorate do not encourage collaboration and team building

\section{Insert Table 8 - here}

Table (8) shows the presence of team learning dimension in the studied population, since it scored an average of 3.95 and a standard deviation of 0.935 . Teams also treat their members as equals, regardless of rank and culture, which is confirmed by a response rate of 4.27 , come next to that is with almost equal rating are items 1,3 and 4 , they confirm a strong team learning culture.

\section{Insert Table 9-here}

Table (9) confirms that the alternative hypothesis (H1c) is accepted since the null hypothesis is rejected, the tvalue is more than the tabulated ( $\mathrm{t})(15.434>1.96)$ and under the significance level of $(\alpha \leq .05)$, which means that management of these banks makes the environment of learning through teams available to everyone.

7.5 Testing the fourth sub-hypothesis HOd, which states systems are not established in the Commercial Banks branches to capture and share learnings

\section{Insert Table 10- here}

Commercial Banks branches in the Governorate of Almafraq were able to build a system capable of capturing and sharing learning as shown in table (10), with slightly high average of 3.94 and a standard deviation of 0.864 .

The variable related to people ability to get needed information any time quickly and easily, scored the highest response with an average of 4.06, followed by organization measures, mainly, the results of the time and resources spent on training with a score of 3.98. On the contrary, maintain an up to recent data base of employee skills got the lowest in rating.

\section{Insert Table 11- here}

Table(10) confirms that the alternative hypothesis (H1d) is accepted since the null hypothesis is rejected, the tvalue is more than the tabulated ( $\mathrm{t})(32.183>1.96)$ and under the significance level of $(\alpha \leq .05)$, which means that the management of these banks built a system capable of capturing and sharing kowledge.

7.6 Testing the fifth sub-hypothesis H0e, which states that people working at the Commercial Banks branches in Almafraq governorate are not empowered toward a collective vision

\section{Insert Table 12- here}

Table 12 illustrates that people in the Commercial Banks empowered toward collective vision but the response rate of (3.79) which is just slightly above the medium average. The item" my organization recognizes people for taking initiative" is the highest in rating followed by " my organization gives people control over the resources they need to accomplish their work", but the lowest is "my organization invites people to contribute to the organization's vision" scoring only 3.55 .

\section{Insert Table 13 - here}

Table (13) confirms that the fifth sub hypothesis is rejected because the t- value is more than the tabulated (t) (12.361> 1.96) and under the significance level of $(\alpha \leq .05)$, therefore the alternative hypothesis (H1e) is accepted, thus we conclude that the researched population is empowered toward collective vision.

7.7 Testing the sixth sub-hypothesis HOf, which states that Commercial Banks branches in Almafraq governorate are not connected with their external environment

\section{Insert Table 14-here}

Table 14 emphasizes that, the researched population is connected with its external environment. The mean of their answers is 3.87 which could be interpreted as a an above average answer, in addition to that the item " My organization encourages people to get answers from across the organization when they face a problem" got the highest in rating compared to others, but the lowest in rating is the item" My organization considers the impact of decisions on employee morale".

\section{Insert Table 15- here}

Table(15) confirms that the sixth sub hypothesis is rejected because the $\mathrm{t}$ - value is more than the tabulated (t) (23.088> 1.96) and under the significance level of $(\alpha \leq .05)$, therefore the alternative hypothesis(H1f) is accepted, so, we conclude that the researched population connected with its external environment.

7.8 Testing the seventh sub-hypothesis HOg, which states that the management of the Commercial Banks branches in Almafraq governorate does not possess leadership model that supports learning.

\section{Insert Table 16- here}

Table 16 shows that, the leadership dimension got a response rate that is 3.87 which is considered high. of Respondents majority agree that the management provides leadership that ignites learning, besides another item got an equal rating which is" In my organization, leaders continually look for opportunities to learn", this result confirms that, leadership is a major requirement for a firm to qualify to be a learning one, The rest of the items got an almost similar rating. 


\section{Insert Table 17- here}

Table (17) shows that the seventh sub hypothesis is rejected because the t- value is more than the tabulated ( $\mathrm{t}$ ) $33.825>1.96)$ and under the significance level of $(\alpha \leq .05)$, therefore the alternative hypothesis $(\mathrm{H} 1 \mathrm{~g})$ is accepted, so, we can conclude that the management of the Commercial Banks branches in Almafraq Governorate does not possess leadership model that supports learning.

\section{Summary of Conclusion}

1). It can be said that the branches of Commercial Banks in the city of Mafraq are learning organizations, and there is no doubt about that. The presence of the dimensions of the learning organization is accepted at this moment, but it is slightly above average, and must be taken with great caution. Thus, the study population have to work on how to improve the environment which improves learning.

2). Environment of continuous learning is prevalent in the branches of Commercial Banks in the province of AL Mafraq, and it is evident from their ability to discuss their mistakes openly and freely to learn from them, Moreover they determine what is required from them in the future to identify the skills necessary to do so. In addition to that, management of these banks provides the necessary resources to facilitate the learning process.

3 ). There is an atmosphere of intimacy and trust among the respondents of the study, and this may be due to the nature of Arab culture that focuses on respect and work valuation. Workers can ask any job related inquiry without any feeling of embarrassment.

4). Learning through teams, would sound like a slogan in some organization but fortunately it is being applied through different means, such as, the equal treatment. Team members receive from each other regardless of position and rank, and freedom of adapting their goals and plans as needed, so researchers believe, this dimension would allow organization to exploit their workers' talents and innovative thinking to an optimal level.

5). Respondents were able to build a system capable of capturing and sharing knowledge, since they have an access to any kind of Job related information, two way communications through electronic and other means is also part of their management rituals. Aside from that, respondents prefer meetings that are conducted in an open place so as to allow the brain storming to take a stronger effect.

6). No empowerment can take place without learning environment. The freedom of taking initiative and appropriate action is practiced among the study respondents but it is only a few lines above the moderate level, which calls for an extra efforts to be exerted by the management of these banks in the future toward more empowerment of employees.

7). The researched organizations are connected to their environments, employees even seek answer to any problem they face from different sources inside the organizations, at the same time they are open to the external environment represented by the external community.

8). The leadership that supports learning opportunities and training, continually learn, and safeguard the value system, is present in the researched organizations in above moderate level, but there is still room for improvement.

\section{Limitations}

This results of study are valid only for Commercial Banks which operate in Almafraq Governorate or another city in Jordan that has common denominators with it. In addition to that, Jordan Banking sector is composed of two types of banking, the Commercial and the Islamic Banking, so the findings of this study are not applied to Islamic Banks because of their different guiding principle.

\section{Recommendations for future research}

Future research may try to relate learning organizations dimensions with factors such as the overall performance, the competitive advantage, and the clients satisfaction of Commercial Banks in Almafraq Governorate in particular and in Jordan in general. Aside from that, future studies can also explore the role that management plays in the evolution and the safeguarding of the learning climate in other industrial sectors. Cooperation of governing agencies preserving the learning atmosphere may also be an area for future investigation.

\section{References}

Abu Khadra M., and Rawabdeh I. (2006). Assessment of development of the learning organization concept in Jordanian industrial companies. The Learning Organization, Vol. 13 No. 5, pp. $455-474$. http://dx.doi.org/10.1108/09696470610679983

Ahmed Al-Hourani. (1979). Banking institutions in Jordan, the second edition. Oman, Central Bank of Jordan, p. 16.

Argyris, C., and Schon, D. (1978). Organizational Learning. Addison-Wesley, Reading, MA.

Bates, R., and Khasawneh S. (2005). Organizational learning culture, learning transfer climate and perceived innovation in Jordanian organizations. International Journal of Training and Development, 9:2. pp96-109. http://dx.doi.org/10.1111/j.1468-2419.2006.00253.x

Calvert, G., Mobley, S., \& Marshall, L. (1994). Grasping the learning organization. Training, Vol. 6, No. 48, pp. 38-44.

Cronbach L J. (1951). Coefficient Alpha and the internal structure of tests. Psychometrika, 16:297-334. 
http://dx.doi.org/10.1007/BF02310555

Cummings, T. J., \& Worley, C. G. (2001). Organization development and change (7th ed.). Cincinnati, OH: Southwestern College.

DiBella, A. (1997). Gearing up to become a learning organization. Journal for Quality \& Participation, 20 (3): $12-5$.

DiBella, A. J., \& Nevis, E. C. (1995). How organizations learn: An integrated strategy for building learning capability. Jossey-Bass Publishers, San Francisco.

Emory, C., and Cooper, D. (1991). Business Research Methods, $4^{\text {th }}$ ed. Homewood, IL:Irwin.

Garvin D. (1993). Building a Learning Organization. Harvard Business Review, Aug., pp. 78-90.

Hedgetts, R.M., F. Luthans and S. Lee. (1994). New paradigm organizations: From total quality learning to word-class. Organizational Dynamics, 23 (3): 4-19.

Hitt, W. D. (1995). The learning organization: Some reflections on organizational. Jossey-Bass, San Fransisco.

Kontoghiorghes, C., Awbrey, S., \& Feuri, P. (2005). Examining the Relationship Between Learning Organization Characteristics and Change Adaptation, Innovation, and Organizational Performance. Human resource development quarterly, vol. 16, no. 2, pp. 185-211. http://dx.doi.org/10.1002/hrdq.1133

Marsick, V. J., \& Watkins, K. E. (1999). Facilitating learning organizations: Making learning count. Aldershot, England: Gower.

Murray, P., and K. Donegan. (2003). Empirical linkages between firm competencies and organizational learning. The Learning Organization, 10, 1, 51-62. http://dx.doi.org/10.1108/09696470310457496

Nachmias, D., and Nachmias, C. (1987). Research Methods in the Social Sciences, $3^{\text {rd }}$ edition. New York: St. Martin's Press.

Nonaka, I. (1991). The knowledge-creating company. Harvard Business Review, 69 (6): 96-104.

Örtenblad, A. (2002). A typology of the idea of learning organization. Management Learning, 33,213-230. http://dx.doi.org/10.1177/1350507602332004

P.E. Jensen. (2005). A Contextual Theory of Learning and the Learning Organization. Knowledge and Process Management, Vol.12, No.1, 53-64. http://dx.doi.org/10.1002/kpm.217

Pedler, M., Burgoyne, J., \& Boydell, T. (1991). The learning company: A strategy for sustainable development. New York: McGraw-Hill.

Prokesch, S. E. (1997). Unleashing the power of learning: An interview with British Petroleum's John Browne. Harvard Business Review, 75 (5): 146- 68.

Roth, G., and A. Kleiner. (1998). Developing organizational memory through Learning histories. Organizational Dynamics, 27 (2): 43-60. http://dx.doi.org/10.1016/S0090-2616(98)90023-7

Senge, P. M. (1990). The leader's new work: Building learning organization. Sloan Management Review, 32 (1): $7-23$.

Senge, P. M. (1996). Leading learning organizations. Training \& Development, 50 (12): 36-7.

Senge, P.M. (1990). The Fifth Discipline: The Art and Practice of the Learning Organization. London, Currency Doubleday.

Slater, S. F., \& Narver, J. C. (1995). Market orientation and the learning organization. Journal of Marketing, 59, 63-74. http://dx.doi.org/10.2307/1252120

Stata, R. (1989). Organizational learning: The key to management innovation. Sloan Management Review, 30 (3): 63-74.

Van der Bent, J., J. Paauwe, and R.Williams. (1999). Organizational learning: An exploration of organizational memory and its role in organizational change processes. Journal of Organizational Change Management, 12 (5): 377-404. http://dx.doi.org/10.1108/09534819910289084

Watkins, K. E., \& Marsick, V. J. (1993). Sculpting the Learning Organization. Jossey-Bass, San Fransisco.

Watkins, K. E., and R. T. Golembiewski. (1995). Rethinking organization development for the learning organization. The International Journal of Organizational Analysis, 3 (1): 86-101. http://dx.doi.org/10.1108/eb028825

Watkins, K.E., and Marsick, V.J. (1996). Creating the Learning Organization. American, Society for Training and Development. Alexandria, VA.

Yang, B., Watkins, K. E., and Marsick, V.J. (2004). The Construct of the Learning Organization: Dimensions, Measurement and Validation. Human Resource Development Quarterly, 15(1), pp.31-55. http://dx.doi.org/10.1002/hrdq.1086 
Table 1. Coefficient of internal consistency

\begin{tabular}{|l|l|l|l|}
\hline Factor & N of Cases & N of Items & Alpha \\
\hline 1. Creating continuous learning opportunity & 65 & $\mathbf{7}$ & 0.763 \\
\hline 2. Promote inquiry and dialogues & 65 & 6 & 0.606 \\
\hline 3. Encourage collaboration and team learning & 65 & $\mathbf{6}$ & 0.897 \\
\hline 4. Establish system to capture and share & 65 & $\mathbf{7}$ & 0.862 \\
\hline 5. Empower people toward a collective vision & 65 & $\mathbf{6}$ & 0.919 \\
\hline 6. Connect the organization to its environment & 65 & $\mathbf{6}$ & 0.920 \\
\hline 7. Providing a strategic leadership for organizational learning & 65 & $\mathbf{8}$ & 0.951 \\
\hline & 0.845 & \multicolumn{3}{l}{} \\
\hline
\end{tabular}

Table 2. Learning organization dimensions

\begin{tabular}{|c|c|c|c|}
\hline Item no. & Paragraphs & Mean & Std. Deviation \\
\hline 1 & Creating continuous learning opportunity & 3.90 & 0.828 \\
\hline 2 & Promote inquiry and dialogues & 3.75 & 1.003 \\
\hline 3 & Encourage collaboration and team learning & 3.95 & 0.935 \\
\hline 4 & Establish system to capture and share knowledge & 3.94 & 0.864 \\
\hline 5 & Empower people toward a collective vision & 3.79 & 0.989 \\
\hline 6 & Connect the organization to its environment & 3.87 & 0.957 \\
\hline \multirow[t]{2}{*}{7} & Providing a strategic leadership for organizational learning & 3.87 & 1.027 \\
\hline & Average & 3.87 & 0.943 \\
\hline
\end{tabular}

Table 3. Main hypothesis one-sample t- test

\begin{tabular}{|c|c|c|c|c|c|c|}
\hline & $\begin{array}{c}\text { 95\% Confidence Interval of } \\
\text { the Difference }\end{array}$ & $\begin{array}{c}\text { Mean } \\
\text { Difference }\end{array}$ & Sig. (2-tailed) & $\mathrm{df}$ & $\mathrm{t}$ & \\
\hline Upper & Lower & & & & & \\
\hline .9201 & .7999 & .8600 & .000 & 7 & 33.825 & Main hypothisis \\
\hline
\end{tabular}

$\alpha \leq .05$

Test Value $=3$

Table 4. Descriptive statistics of crating continuous learning opportunity

\begin{tabular}{|l|l|l|l|}
\hline $\begin{array}{l}\text { Item } \\
\text { order }\end{array}$ & Item & Mean & $\begin{array}{l}\text { Std. } \\
\text { Deviation }\end{array}$ \\
\hline $\mathbf{1}$ & $\begin{array}{l}\text { In my organization, people openly discuss mistakes in order to learn from } \\
\text { them }\end{array}$ & 4.23 & 1.031 \\
\hline $\mathbf{2}$ & In my organization, people identify skills they need for future work tasks & 3.89 & 0.943 \\
\hline $\mathbf{3}$ & In my organization, people help each other learn & 3.89 & 1.161 \\
\hline $\mathbf{4}$ & $\begin{array}{l}\text { In my organization, people can get money and other resources to support } \\
\text { their learning }\end{array}$ & 3.89 & 0.791 \\
\hline $\mathbf{5}$ & In my organization, people are given time to support learning & 3.68 & 0.988 \\
\hline 6 & $\begin{array}{l}\text { In my organization, people view problems in their work as an opportunity } \\
\text { to learn }\end{array}$ & 3.65 & 1.175 \\
\hline 7 & In my organization, people are rewarded for learning & 3.56 & 1.110 \\
\hline & Mean & $\mathbf{3 . 9 0}$ & $\mathbf{0 . 8 2 8}$ \\
\hline
\end{tabular}

Table 5. One-Sample Test of the first sub- hypothesis

\begin{tabular}{|c|c|c|c|c|c|}
\hline Continuous learning & & & & $\begin{array}{c}\text { Test Value }= \\
3\end{array}$ \\
\hline & $\begin{array}{c}95 \% \text { Confidence Interval of } \\
\text { the Difference }\end{array}$ & Mean Difference & $\begin{array}{c}\text { Sig. } \\
\text { (2-tailed) }\end{array}$ & $\mathrm{df}$ & $\mathrm{t}$ \\
\hline Upper & Lower & & & & \\
\hline 1.0334 & .6208 & .8271 & .000 & 6 & 9.811 \\
\hline
\end{tabular}


Table 6. Descriptive statistics of the promotion of dialogue and inquiry

\begin{tabular}{|c|l|c|c|}
\hline $\begin{array}{l}\text { Paragraph } \\
\text { no. }\end{array}$ & \multicolumn{1}{|c|}{ Paragraphs } & Mean & Std. Deviation \\
\hline $\mathbf{1}$ & $\begin{array}{l}\text { In my organization, people give open and honest feedback to } \\
\text { each other }\end{array}$ & 3.71 & 1.151 \\
\hline $\mathbf{2}$ & $\begin{array}{l}\text { In my organization, people listen to others' views before } \\
\text { speaking }\end{array}$ & 3.69 & 1.080 \\
\hline $\mathbf{3}$ & $\begin{array}{l}\text { In my organization, people are encouraged to ask "why" } \\
\text { regardless of rank }\end{array}$ & 3.58 & 1.139 \\
\hline $\mathbf{4}$ & $\begin{array}{l}\text { In my organization, whenever people state their view, they also } \\
\text { ask what others think }\end{array}$ & 3.50 & 1.067 \\
\hline $\mathbf{5}$ & In my organization, people treat each other with respect & 3.92 & 1.271 \\
\hline $\mathbf{6}$ & $\begin{array}{l}\text { In my organization, people spend time building trust with each } \\
\text { other }\end{array}$ & 3.79 & 1.133 \\
\hline & Mean & $\mathbf{3 . 7 5}$ & $\mathbf{1 . 0 0 3}$ \\
\hline
\end{tabular}

Table 7. One-Sample Test of the second sub- hypothesis

\begin{tabular}{|c|c|c|c|c|c|c|}
\hline & $\begin{array}{c}95 \% \text { Confidence Interval of the } \\
\text { Difference }\end{array}$ & $\begin{array}{c}\text { Mean } \\
\text { Difference }\end{array}$ & $\begin{array}{c}\text { Sig. } \\
\text { (2-tailed) }\end{array}$ & df & $\mathrm{t}$ & \\
\hline Upper & Lower & & & & & \\
\hline .8548 & .5419 & .6983 & .000 & 5 & 11.476 & Dialogue \& inquiry \\
\hline
\end{tabular}

Table 8. Descriptive statistics of team learning dimension

\begin{tabular}{|c|l|c|c|}
\hline $\begin{array}{c}\text { Paragraph } \\
\text { no. }\end{array}$ & \multicolumn{1}{|c|}{ Paragraphs } & Mean & $\begin{array}{c}\text { Std. } \\
\text { Deviation }\end{array}$ \\
\hline $\mathbf{1}$ & $\begin{array}{l}\text { In my organization, teams/groups have the freedom to adapt their goals } \\
\text { as needed }\end{array}$ & 4.06 & .939 \\
\hline $\mathbf{2}$ & $\begin{array}{l}\text { In my organization, teams/groups treat members as equals, regardless } \\
\text { of rank, culture, or other differences }\end{array}$ & 4.27 & .853 \\
\hline $\mathbf{3}$ & $\begin{array}{l}\text { In my organization, teams/groups focus both on the group's task and on } \\
\text { how well the group is working }\end{array}$ & 4.05 & .895 \\
\hline $\mathbf{4}$ & $\begin{array}{l}\text { In my organization, teams/groups revise their thinking as a result of } \\
\text { group discussions or information collected }\end{array}$ & 4.03 & .923 \\
\hline $\mathbf{5}$ & $\begin{array}{l}\text { In my organization, teams/groups are rewarded for their achievements } \\
\text { as a team/group }\end{array}$ & 3.84 & 1.119 \\
\hline $\mathbf{6}$ & $\begin{array}{l}\text { In my organization, teams/groups are confident that the organization } \\
\text { will act on their recommendations }\end{array}$ & 3.84 & 1.119 \\
\hline & Mean & $\mathbf{3 . 9 5}$ & $\mathbf{0 . 9 3 5}$ \\
\hline
\end{tabular}

Table 9. One-Sample Test of the third sub- hypothesis

\begin{tabular}{|c|c|c|c|c|c|c|}
\hline & $\begin{array}{c}95 \% \text { Confidence Interval of the } \\
\text { Difference }\end{array}$ & Mean Difference & $\begin{array}{c}\text { Sig. } \\
(2-\text { tailed })\end{array}$ & $\mathrm{df}$ & $\mathrm{t}$ & \\
\hline Upper & Lower & & & & & \\
\hline 1.1841 & .8459 & 1.0150 & .000 & 5 & 15.434 & Team learning \\
\hline
\end{tabular}


Table 10. Descriptive statistics of embedded system dimension

\begin{tabular}{|c|l|c|c|}
\hline $\begin{array}{l}\text { Paragraph } \\
\text { no. }\end{array}$ & \multicolumn{1}{|c|}{ Paragraphs } & Mean & $\begin{array}{c}\text { Std. } \\
\text { Deviation }\end{array}$ \\
\hline $\mathbf{1}$ & $\begin{array}{l}\text { My organization uses two-way communication on a regular basis, such } \\
\text { as suggestion systems, electronic bulletin }\end{array}$ & 3.98 & 1.094 \\
\hline $\mathbf{2}$ & boards, or town hall/open meetings & 3.97 & .975 \\
\hline $\mathbf{3}$ & $\begin{array}{l}\text { My organization enables people to get needed information at any time } \\
\text { quickly and easily }\end{array}$ & 4.06 & .990 \\
\hline $\mathbf{4}$ & My organization maintains an up-to-date data base of employee skills & 3.81 & .938 \\
\hline $\mathbf{5}$ & $\begin{array}{l}\text { My organization creates systems to measure gaps between current and } \\
\text { expected performance }\end{array}$ & 3.94 & .990 \\
\hline $\mathbf{6}$ & My organization makes its lessons learned available to all employees & 3.90 & 1.020 \\
\hline $\mathbf{7}$ & $\begin{array}{l}\text { My organization measures the results of the time and resources spent on } \\
\text { training }\end{array}$ & 3.98 & 1.094 \\
\hline & Mean & $\mathbf{3 . 9 4}$ & $\mathbf{0 . 8 6 4}$ \\
\hline
\end{tabular}

Table 11. One-Sample Test of the fourth sub- hypothesis

\begin{tabular}{|c|c|c|c|c|c|c|}
\hline & $\begin{array}{c}95 \% \text { Confidence Interval of the } \\
\text { Difference }\end{array}$ & $\begin{array}{c}\text { Mean } \\
\text { Difference }\end{array}$ & Sig. (2-tailed) & df & $\mathrm{t}$ & \\
\hline Upper & Lower & & & & & \\
\hline 1.0207 & .8765 & .9486 & .000 & 6 & 32.183 Embedded systems \\
\hline
\end{tabular}

Table 12. Descriptive statistics of empowerment dimension

\begin{tabular}{|c|c|c|c|}
\hline $\begin{array}{l}\text { Paragraph } \\
\text { no. }\end{array}$ & Paragraphs & Mean & $\begin{array}{c}\text { Std. } \\
\text { Deviation }\end{array}$ \\
\hline 1 & My organization recognizes people for taking initiative & 3.89 & 1.147 \\
\hline 2 & My organization gives people choices in their work assignments & 3.66 & 1.023 \\
\hline 3 & $\begin{array}{l}\text { My organization invites people to contribute to the organization's } \\
\text { vision }\end{array}$ & 3.55 & 1.141 \\
\hline 4 & $\begin{array}{l}\text { My organization gives people control over the resources they need to } \\
\text { accomplish their work }\end{array}$ & 3.85 & 1.114 \\
\hline 5 & My organization supports employees who take calculated risks & 3.58 & 1.124 \\
\hline 6 & $\begin{array}{l}\text { My organization builds alignment of visions across different levels } \\
\text { and work groups }\end{array}$ & 3.69 & 1.080 \\
\hline & Mean & 3.79 & 0.989 \\
\hline
\end{tabular}

Table 13. One-Sample Test of the fifth sub- hypothesis

\begin{tabular}{|c|c|c|c|c|c|c|}
\hline & $\begin{array}{c}\text { 95\% Confidence Interval of } \\
\text { the Difference }\end{array}$ & $\begin{array}{c}\text { Mean } \\
\text { Difference }\end{array}$ & Sig. (2-tailed) & $\mathrm{df}$ & $\mathrm{t}$ & \\
\hline Upper & Lower & & & & & \\
\hline .8496 & .5571 & .7033 & .000 & 5 & 12.361 & Empowerment \\
\hline
\end{tabular}


Table 14. Descriptive statistics of System Connections dimension

\begin{tabular}{|c|l|c|c|}
\hline $\begin{array}{c}\text { Paragraph } \\
\text { no. }\end{array}$ & \multicolumn{1}{|c|}{ Paragraphs } & Mean & $\begin{array}{c}\text { Std. } \\
\text { Deviation }\end{array}$ \\
\hline $\mathbf{1}$ & My organization helps employees balance work and family & 3.84 & 1.134 \\
\hline $\mathbf{2}$ & My organization encourages people to think from a global perspective & 3.73 & .995 \\
\hline $\mathbf{3}$ & $\begin{array}{l}\text { My organization encourages everyone to bring the customers' views } \\
\text { into the decision making process }\end{array}$ & 3.73 & 1.074 \\
\hline $\mathbf{4}$ & My organization considers the impact of decisions on employee morale & 3.68 & 1.004 \\
\hline $\mathbf{5}$ & $\begin{array}{l}\text { My organization works together with the outside community to meet } \\
\text { mutual needs }\end{array}$ & 3.82 & 1.064 \\
\hline $\mathbf{6}$ & $\begin{array}{l}\text { My organization encourages people to get answers from across the } \\
\text { organization when they face a problem }\end{array}$ & 3.90 & 1.036 \\
\hline & Mean & $\mathbf{3 . 8 7}$ & $\mathbf{0 . 9 5 7}$ \\
\hline
\end{tabular}

Table 15. One-Sample Test of the sixth sub- hypothesis

\begin{tabular}{|c|c|c|c|c|c|c|}
\hline & $\begin{array}{c}95 \% \text { Confidence Interval of } \\
\text { the Difference }\end{array}$ & $\begin{array}{c}\text { Mean } \\
\text { Difference }\end{array}$ & Sig. (2-tailed) & $\mathrm{df}$ & $\mathrm{t}$ & \\
\hline Upper & Lower & & & & & \\
\hline .8705 & .6961 & .7833 & .000 & 5 & 23.088 & System connection \\
\hline
\end{tabular}

Table 16. Descriptive statistics of the leadership dimension

\begin{tabular}{|c|l|c|c|}
\hline $\begin{array}{l}\text { Paragraph } \\
\text { no. }\end{array}$ & \multicolumn{1}{|c|}{ Paragraphs } & \multicolumn{1}{|c|}{ Mean } & $\begin{array}{c}\text { Std. } \\
\text { Deviation }\end{array}$ \\
\hline $\mathbf{1}$ & Provide Leadership & 3.97 & 1.008 \\
\hline $\mathbf{2}$ & $\begin{array}{l}\text { In my organization, leaders generally support requests for learning } \\
\text { opportunities and training }\end{array}$ & 3.85 & 1.084 \\
\hline $\mathbf{3}$ & $\begin{array}{l}\text { In my organization, leaders share up to date information with } \\
\text { employees about competitors, industry trends and }\end{array}$ & 3.84 & 1.059 \\
\hline $\mathbf{4}$ & organizational directions & 3.82 & 1.094 \\
\hline $\mathbf{5}$ & $\begin{array}{l}\text { In my organization, leaders empower others to help carry out the } \\
\text { organization's vision }\end{array}$ & 3.79 & 1.175 \\
\hline $\mathbf{6}$ & $\begin{array}{l}\text { In my organization, leaders mentor and coach those they lead } \\
\mathbf{7}\end{array}$ & In my organization, leaders continually look for opportunities to learn \\
\hline $\mathbf{8}$ & $\begin{array}{l}\text { In my organization, leaders ensure that the organization's actions are } \\
\text { consistent with its values }\end{array}$ & 3.79 & 1.230 \\
\hline & Mean & 3.85 & 1.008 \\
\hline
\end{tabular}

Table 17. One-Sample Test of the seventh sub- hypothesis

\begin{tabular}{|c|c|c|c|c|c|c|}
\hline & $\begin{array}{c}\text { 95\% Confidence } \\
\text { Interval of the } \\
\text { Difference }\end{array}$ & $\begin{array}{c}\text { Mean } \\
\text { Difference }\end{array}$ & Sig. (2-tailed) & $\mathrm{df}$ & $\mathrm{t}$ & \\
\hline Upper & Lower & & & & & \\
\hline .9201 & .7999 & .8600 & .000 & 7 & 33.825 & Solving problem \\
\hline
\end{tabular}

